\title{
Description of Covid-19 Cases in Brazil and Italy
}

\author{
Luiz Philipe de Souza Ferreira ${ }^{1}$ (D) Thiago Maciel Valente ${ }^{2} \cdot$ Fernanda Assunção Tiraboschi $^{2} \cdot$ \\ Guilherme Pinheiro Ferreira da Silva ${ }^{1,3}$
}

Accepted: 6 May 2020 / Published online: 12 May 2020

(C) Springer Nature Switzerland AG 2020

\begin{abstract}
The emergence of Covid-19 started in China and has rapidly spread across the globe, notably in Italy and more recently to Brazil. This is a very worrying situation for the affected countries. This Brief Communication aims to describe and correlate the number of confirmed cases and deaths of Covid-19 in Brazil and Italy. This is a descriptive and retrospective study that used data collated on the World Health Organization (WHO) online platform between 21 January and 19 April 2020. After analyzing the data, it was observed that the number of confirmed cases and deaths in Brazil is lower than that in Italy. There are certain factors in Brazil which see it in a lower risk position than Italy; however, despite the current slow spread of the virus, the situation in Brazil is difficult to predict.
\end{abstract}

Keywords COVID-19 $\cdot$ Epidemiology $\cdot$ Coronavirus disease $\cdot$ COVID-19 $\cdot 2019-n C o V \cdot$ Pandemic

\section{Introduction}

In Wuhan City, Hubei, China, on December 31, 2019, pneumonia cases of unknown etiology were reported to the government. Forty-four patients had pneumonia during the period from December 31, 2019, to January 3, 2020 [1, 2]. Between 11 and 12 of January, it was discovered that the unknown etiology was associated with the free sale of seafood and wild animals in the Wuhan market. The spread of Covid-19 occurred quickly, a total of 282 cases had been confirmed in China, 2 cases in Thailand, 1 case in Japan, and 1 case in the Republic of Korea [1-3].

The virus spread rapidly in the western Pacific, Southeast Asia, Eastern Mediterranean, African, and European regions, registering two cases in Italy on January 31, 2020, before arriving in the Americas $[4,5]$ and spreading to Brazil, where

This article is part of the Topical Collection on Covid-19

Luiz Philipe de Souza Ferreira philipedesouza@edu.unifor.br

1 Department of Physiotherapy, Division of Health Sciences Center, University of Fortaleza (UNIFOR), Fortaleza, CE, Brazil

2 Department of Medicine, Division of Health Sciences Center, University of Fortaleza (UNIFOR), Fortaleza, CE, Brazil

3 Federal University of Ceará (UFC), Fortaleza, CE, Brazil the first confirmed case of Covid-19 infection was registered on February 27, 2020 [6, 7].

The appearance of Covid-19 demonstrates a concern for Brazil, which has previously dealt with socioeconomic problems since the arrival of other endemic viral pathologies, such as dengue, Zika virus (ZIKV), and chikungunya in 2013 [8]. Zika virus was declared a national public health emergency by the Brazilian Ministry of Health in 2015 and a public health emergency of international concern by the World Health Organization (WHO) in 2016 [9, 10]. In January 2016, 30,000 cases of infection and 1118 suspected cases of microcephaly were registered, a consequence of vertical transmission caused by ZIKV [10].

Currently the global number of confirmed cases of Covid19 exceeds 2,241,778. In Brazil 33,682 confirmed cases were registered until April 19, 2020, and in Italy 175,925 cases were confirmed [4].

Emergencies like these are a major cause of concern for countries and therefore the objective of this research is to describe and correlate the number of confirmed cases of Covid-19 in Brazil and Italy and correlate the number of reported deaths, notified by national authorities and released by the WHO.

\section{Methodology}

This is a descriptive and retrospective study, which was carried out using the data on the WHO online platform (accessed 


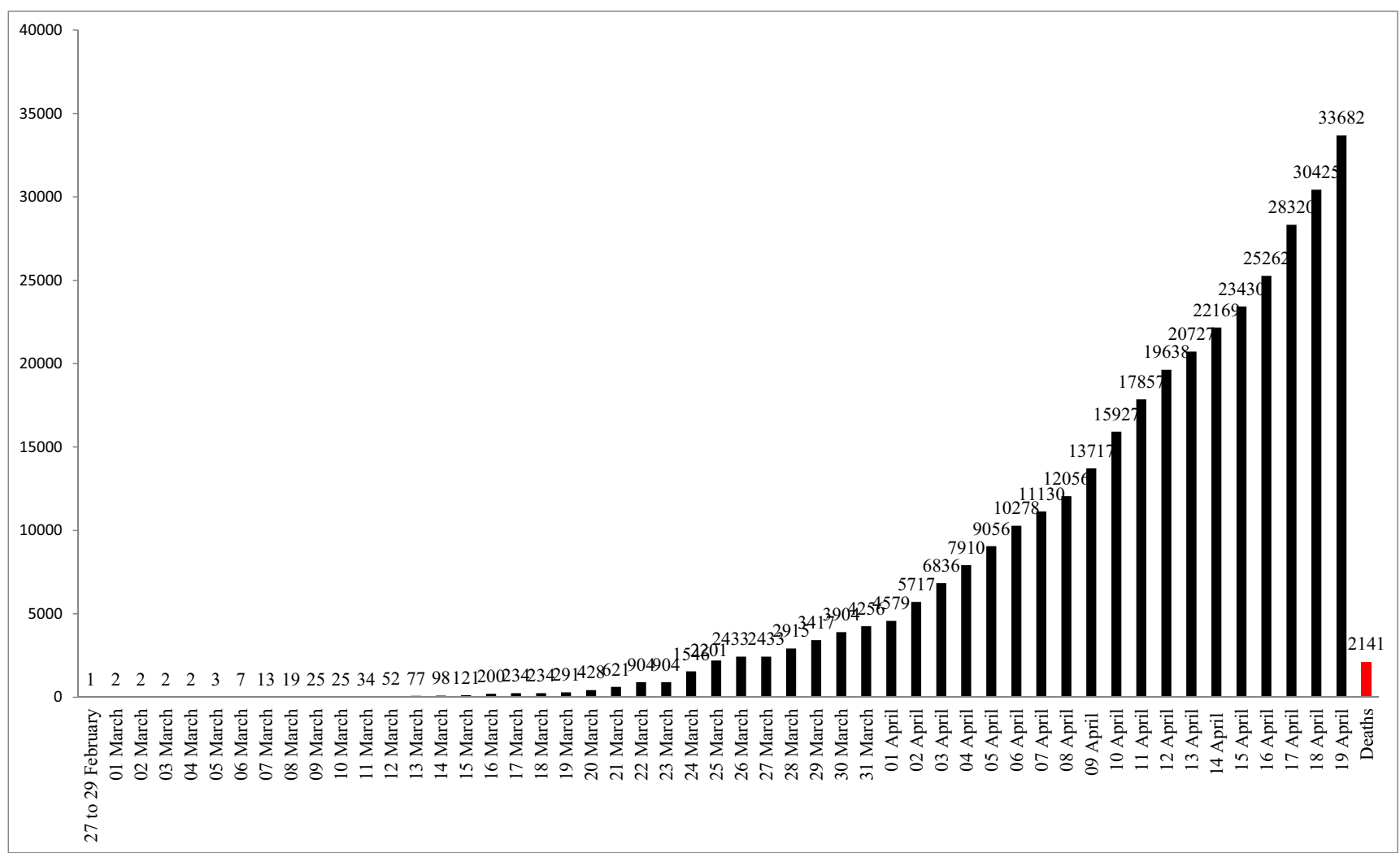

Fig. 1 Total number of confirmed Covid-19 cases in Brazil 27 February 2020 to 19 April 2020 and total deaths

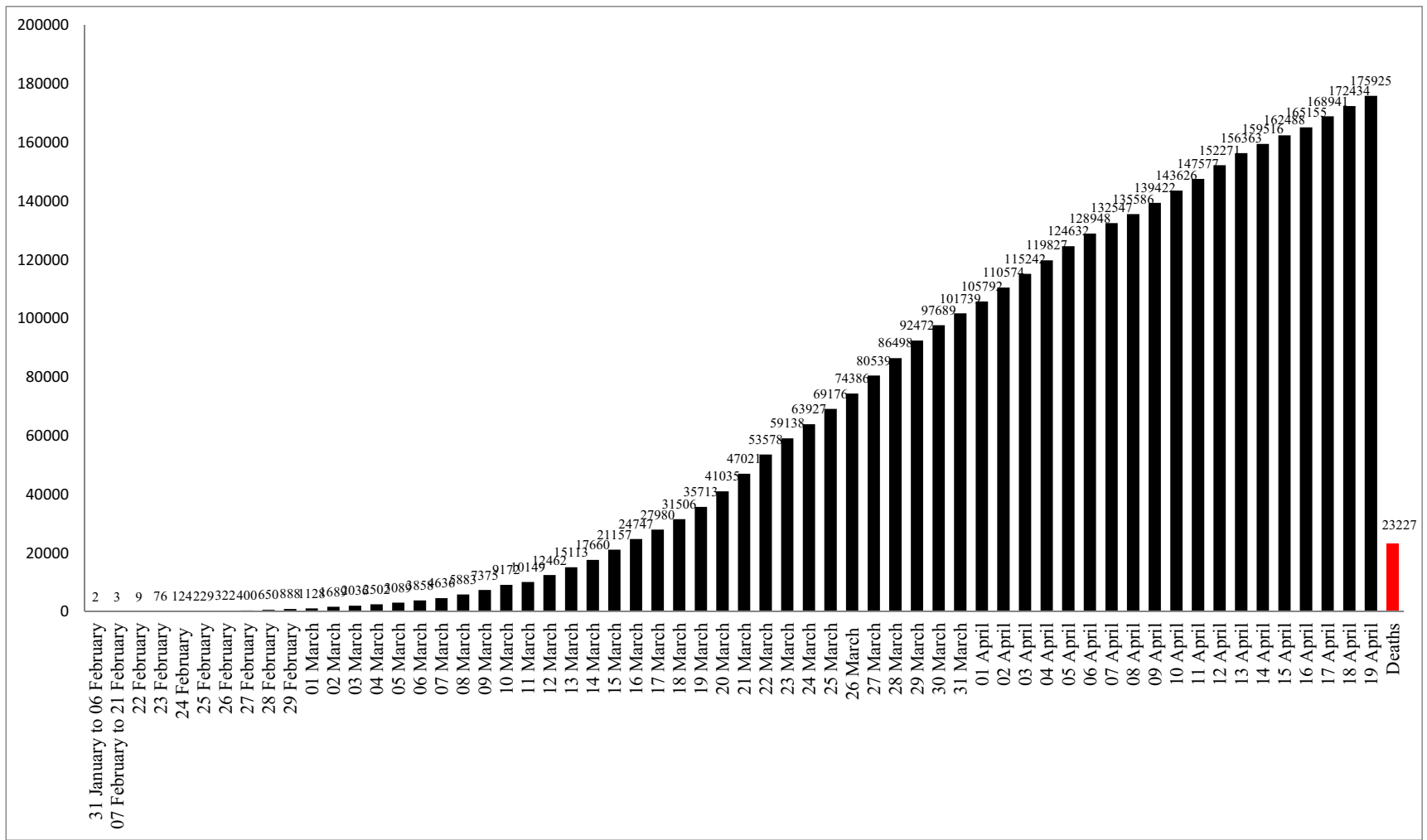

Fig. 2 Total number of confirmed Covid-19 cases in Italy 31 January 2020 to 19 April 2020 and total deaths 
April 19, 2020). The criteria used in the search were "Coronavirus disease AND COVID-19"; "COVID-19 AND Situation reports."

A total of 90 reports were reported in the period 21 January 2020 to 19 April 2020.

This study included the total number of confirmed cases and deaths of COVID-19 infection in Brazil and Italy, excluding all confirmed cases and deaths in other countries. Data was extracted from the platform and using Microsoft Office $365 \AA$, Microsoft Word®, and a graph was automatically generated in Excel®.

The extracted data was then tabulated according to the reported dates and their respective number of confirmed cases and deaths in decreasing to increasing order, example:

Situation report-01, 21 January 2020,

Situation report-02, 22 January 2020 , and so on until the

Situation report-90,19 April 2020, the end date of our search criteria.

\section{Results}

Data extracted from the WHO online platform, available at (https://www.who.int/emergencies/diseases/novelcoronavirus-2019/situation-reports), show significant differences between the number of confirmed cases and deaths of Covid-19 in Brazil and Italy. In Brazil, the number of confirmed cases reported by national authorities is 33,682 cases and 2141 deaths [4] up until 19 April 2020, as shown in Fig. 1. Compared with Brazil, the numbers in Italy are much higher with the total number of cases equalling 175,925 and deaths numbering 23,227 [4], as shown in Fig. 2.

\section{Discussion}

Regardless of the affected country, a pandemic is of course an extremely worrying situation since it provokes an unknown period of doubt and uncertainty for the socioeconomic and public health infrastructure of the affected region.

In recent years, the WHO has warned about the worrying pattern in which twenty-first century pandemics are presenting themselves, spreading faster and wider across the world. An example was the last influenza pandemic in 2009, which in less than 9 weeks was already present on all continents [11].

COVID-19 has been very similar, spreading rapidly across the continents to leave the WHO no choice but to declare the virus as a pandemic on 11 March, approximately 13 weeks after the first case being reported in China $[12,13]$.
While there is still no vaccine available, the coronavirus poses a major health concern due to its ability to develop into fatal cases, especially in the elderly with comorbidities, and because of its rapid diffusion, being capable of generating ten times more cases than the SARS (severe acute respiratory syndrome) epidemic in Asia of the (SARS) in a quarter of the time [14].

In some countries, such as Italy, the situation is increasingly threatening; up until 16 March, there were already more than 24,000 confirmed cases, of which almost $10 \%$ being health professionals, resulting in a chronic shortage of support in the health sector [15].

Although the results are currently more favorable in Brazil, there are several factors that must be considered between the two countries, such as age pyramid, territorial dimension, and population size.

The age issue is a positive factor for Brazil, since its age pyramid still has a broad base composed of young people, unlike Italy which has a much broader summit representing the elderly generation. COVID-19 infection tends to be more severe in older individuals, especially those with comorbidities; therefore, the age of the population is a favorable factor for Brazil, and this is manifested by the large number of deaths in Italy [16].

Another factor is the number of inhabitants distributed in the region, since, although Brazil has more than 200 million inhabitants, while Italy has close to 60 million, the Brazilian territory is almost 30 times larger, and thus has a much lower population density $[16,17]$.

Thus, the Brazilian situation is still difficult to predict, although so far it has shown a less serious development than compared with Italy. It is clear that there is a significant difference in the epidemiological curves illustrated in this research; Italy has an increasing non-linear curve (Fig. 2), but it is stabilizing, and seems to be progressing towards a decrease in the number of cases, whereas Brazil maintains its non-linear curve but is notoriously showing a daily exponential increase in the number of confirmed cases (Fig. 1).

\section{Conclusion}

The number of confirmed cases and deaths of Covid-19 in Italy is higher when compared with Brazil. Social distancing and isolation measures by the WHO appear to be useful in slowing down the rate of new cases, but other solutions must be adopted by Brazil to reduce the number of cases. The numbers of confirmed Brazilian are not expected to reach the scale of the Italian situation since Brazil has a younger and more dispersed demographic.

\section{Compliance with Ethical Standards}

Conflict of Interest The authors declare that they have no conflict of interest. 
Ethics Statements Not applicable. This is a descriptive and retrospective study that extracted data from the WHO online platform and does not undermine the principles according to the ethical standards established in the 1964 Declaration of Helsinki.

\section{References}

1. WHO. WHO travel advice for international travel and trade in relation to the outbreak of pneumonia caused by a new coronavirus in China. 2020; Available from: https://www.who.int/ith/20200901 outbreak_of_Pneumonia_caused_by_a_new_coronavirus_in_C/ en/ Accessed 20 March 2020.

2. Zhu N, Zhang D, Wang W, Li X, Yang B, Song J, et al. A novel coronavirus from patients with pneumonia in China, 2019. N Engl J Med. 2020;382(8):727-33.

3. Benvenuto D, Giovanetti M, Ciccozzi A, Spoto S, Angeletti S, Ciccozzi M. The 2019-new coronavirus epidemic: evidence for virus evolution. J Med Virol. 2020;92(4):455-9.

4. WHO. Novel coronavirus $(2019-\mathrm{nCoV})$ : situation report -90 . 2020; Available from: https://wwwwhoint/docs/default-source/ coronaviruse/situation-reports/20200419-sitrep-90-covid-19pdf? sfvrsn=551d47fd 4 Acessed 18 April 2020.

5. WHO. Novel coronavirus $(2019-\mathrm{nCoV})$ : situation report -11 . 2020; Available from: https://wwwwhoint/docs/default-source/ coronaviruse/situation-reports/20200131 sitrep-11-ncovpdf? sfvrsn=de7c0f7_4 Acessed 20 March 2020.

6. WHO. Novel coronavirus $(2019-\mathrm{nCoV})$ : situation report -38 . 2020; Available from: https://www.who.int/docs/default-source/ coronaviruse/situation-reports/20200227-sitrep-38-covid-19.pdf? sfvrsn=2db7a09b_4 Accessed 20 March 2020 .

7. Rodriguez-Morales AJ, Gallego V, Escalera-Antezana JP, Mendez CA, Zambrano LI, Franco-Paredes C, et al. COVID-19 in Latin America: the implications of the first confirmed case in Brazil. Travel Med Infect Dis. 2020;101613.
8. De Lima CT, Durães-Carvalho R, Rezende AM, De Carvalho OV, Kohl A, Wallau GL, et al. Revisiting key entry routes of human epidemic arboviruses into the mainland Americas through largescale phylogenomics. Int J Genomics. 2018;6941735.

9. Diniz SG, Andrezzo HF. Zika virus - the glamour of a new illness, the practical abandonment of the mothers and new evidence on uncertain causality. Reprod Health Matters. 2017;25(49):21-5.

10. Faria NR, Do Socorro Da Silva Azevedo R, Kraemer MUG, Souza $\mathrm{R}$, Cunha MS,Hill SC et al. Zika virus in the Americas: early epidemiological and genetic findings. Science. 2026;352(6283):345349.

11. WHO. Managing epidemics: key facts about major deadly diseases managing epidemics. Available from: https://appswhoint/iris/ handle/10665/272442 Accessed. 2018;(March 19, 2020).

12. OPAS/OMS BRASIL. OMS afirma que COVID-19 é agora caracterizada como pandemia. 2020; Available from:https://www. paho.org/bra/index.php?option=com_content\&view=article\&id= 6120:oms-afirma-que-covid-19-e-agora-caracterizada-comopandemia\&Itemid=812. Accessed 22 March 2020.

13. Lancet Infectious Diseases. 2020. Editorial COVID-19, a pandemic or not?. Available from: https://doi.org/10.1016/S1473-3099 Accessed 22 March 2020.

14. Gates B. Responding to Covid-19 — a once-in-a-century pandemic?. New Engl J Med . 2020; 1-3.

15. Paterlini M. On the front lines of coronavirus: the Italian response to covid-19. BMJ. 2020;368:m1065.

16. UNITED NATIONS. World population prospects. 2019; Available from: https://population.un.org/wpp/Graphs/Probabilistic/POP/ TOT/380 Accessed 22 March 2020.

17. UNITED NATIONS. Environment statistics. 2016; Available from: https://unstats.un.org/unsd/environment/totalarea.htm Accessed 22 March 2020.

Publisher's Note Springer Nature remains neutral with regard to jurisdictional claims in published maps and institutional affiliations. 